\title{
Designing Web 2.0 Tools for Online Public Consultation
}

\author{
Fabro Steibel and Elsa Estevez
}

Public consultation is a formal mechanism of social participation where government invites citizens to participate in policymaking. Increasingly, public consultations are being held online, where Web 2.0 tools and other information and communication technology (ICT) tools become central to understand the design of virtual spaces for government-citizen interaction. Through the analysis of two case studies from Brazil-the "Gabinete Digital" and the "Marco Civil Regulatório" initiativesthis chapter discusses how online public consultation spaces are designed, using a combination of ICTs. Based on three frameworks of deliberative theory and characteristics of Web 2.0 tools, the aim of our paper is studying what aspects of Web 2.0 tools are useful for online consultation and what democratic environments they might generate when combined. The main contribution of this work is raising awareness on how the usage of certain Web 2.0 tools can reinforce or diminish some attributes of political communication and therefore, as a result, produce different models of online democratic communication.

\section{Introduction}

Public consultation is a formal mechanism of social participation where government invites the general public to participate in policymaking (Shane 2004). Increasingly, public consultations are being held online, where Web 2.0 and other ICT tools

\author{
F. Steibel $(\bowtie)$ \\ Institute for Technology \& Society of Rio de Janeiro, Praia do Flamengo, 100, Rio de Janeiro, \\ RJ 20010-030, Brazil \\ e-mail: ofabro@ofabro.com \\ E. Estevez \\ United Nations University, Operating Unit on Policy-driven Electronic Governance \\ (UNU-EGOV), Rua Vila Flor 166, 4810-445 Guimarães, Portugal \\ e-mail: estevez@unu.edu \\ A. Chib et al. (eds.), Impact of Information Society Research in the Global South, \\ DOI 10.1007/978-981-287-381-1_13
}


become central to understand the design of virtual spaces for government-citizen interaction (Coleman and Shane 2012). Given the relevance of public consultation for democratic events, and the potential of applying ICT tools in such processes, investigations on this field have recently raised interest within the research community. Application areas of public consultations include drafting legislation, urban planning, election monitoring and participatory budgeting preparation, among others. This research focuses on online public consultations applied for drafting legislation.

The medium of law gives legitimacy to the political order and provides it with its binding force. Legitimate lawmaking itself is generated through a procedure of public opinion and will-formation (Habermas 1996). However, drafting legislation is a hermetic process mostly driven and managed by governments. Such process can be opened to the citizenry through public consultation, which usually follows two types of approaches-top-down and bottom-up. Experiences following a topdown approach are started by government and aim at engaging society. Experiences following a bottom-up approach are started in society and aim at mobilising government for listening to public concerns. In particular, top-down initiatives of e-rulemaking — “a deliberate agenda-setting process designed to elicit, sort, and clarify fact and opinion from a wide variety of interested parties" (Fountain 2003) are known for being too technical for non-specialised audiences, bureaucratically complex and polarised (Åström and Grönlund 2012). At the same time, such initiatives are known for producing policymaking outputs tied in an accountable way to actual governmental policymaking (Coleman and Price 2012). Consequently, challenges remain high for those willing to enrol in lawmaking experiences even when opportunities to participate are real.

To overcome some of the challenges described above, Web 2.0 tools appear useful and innovative. Web 2.0 tools are increasingly popular across different segments of society, and digital barriers, although still present, are gradually being reduced (Norris 2001). Although a complex term to be set, Web 2.0 can be understood in at least three different ways: (1) as a set of social relationships and practices, (2) as a mode of production and (3) as a set of values (Postigo 2011). In this work, Web 2.0 refers to the term as coined by O'Reilly (2005), focusing on the use of collaborative tools that require no specialised knowledge and allow content generated by users to be reused by others in their own social networks.

From this point of view, it seems that Web 2.0 tools have the potential to revolutionise how legislation is made, but it is not clear how politics and technology should interact (Wright and Street 2007). Based on that, the aim of our research is to study how Web 2.0 tools are used to enhance collaborative practices in policymaking, particularly in drafting legislation, and how they affect political communication during the first two stages of the policy life cycle-agenda setting and policy formulation. To achieve the aim, we address the research questions of (1) what aspects of Web 2.0 tools are used by online consultations and (2) what democratic environments are generated by combining different Web 2.0 tools. Our methodology to address these questions is based on an evaluation of two case studies of online public consultation that took place in Brazil. For each case, we analyse 
what Web 2.0 tools were used and group them according to their features. We then assess to what extent they are able to deliver a set of indicative attributes based on three models of democratic communication (as suggested by Freelon 2010).

The rest of this chapter is structured as follows. Section 2 presents our literature review, focusing on defining online consultation as a form of collaborative policymaking, analysing how web tools relate to policymaking life cycle stages and how a framework of democratic theory can explain the uses of web tools for opening up government. Section 3 introduces our methodology, justifying the rationales for selecting case studies and conducting data analysis. Section 4 presents and analyses the two case studies, while Sect. 5 presents our contribution to forecast future uses of online tools for policymaking, as well as introduces policy recommendations to aid policymakers, ICT developers and civil society activists to improve the use of Web 2.0 tools in opening up government for collaborative policymaking. It also draws some conclusions and outlines future work.

\section{Literature Review}

This section presents related work that enables to frame our research work within the state of the art. First, we discuss the relationship between democratic experiences and online consultations. By defining online consultations as object of study, we explain their relevance within current issues of political theory and public policy formulation (Sect. 2.1). Second, we introduce main concepts related to policy design and policy cycle stages, illustrating them with practical cases of online consultations (Sect. 2.2). Third, we introduce models of democratic communication and explain the relevance of using Web 2.0 tools as part of such models (Sect. 2.3).

\subsection{Democratic Experience and Online Consultations}

Relations between members of the public and holders of political authority are in a period of transformative flux. Claims regarding the Internet's potential to reshape democratic life have proceeded through several waves, from early enthusiasm to pessimistic reactions, from theory-driven speculations to empirically driven approaches (Chadwick 2006; Coleman and Blumler 2009; Norris 2000). It is not an objective of this chapter to align the role of online consultations to one wave or another, but rather to support the argument that the Internet "possesses a vulnerable potential to revitalise our flagging political communication arrangements by injecting some new and different elements into the relationship between representatives and represented and governments and governed" (Coleman and Blumler 2009: p. 13). In other words, we assume that Internet has the potential to reshape democracy, although the realisation of this potential relies on a case-by-case analysis. 
Online public consultations, and e-rulemaking in general, are far from a new phenomenon (Benjamin 2006). The interest of using the Internet to revive participatory democracy emerged in the mid-1990s, but the overall participatory movement in governance is situated in the broader context that took place during the 1960s and 1970s (Chadwick 2006). "Listening to the public" increasingly emerged as a necessity of democratic government when citizens became more educated, politically volatile and less differential, what lead politicians to increasingly rely on mechanisms of consultation to plan and evaluate policy decisions (Bimber 2003).

The debate on online public consultations influences the process of formulation of public policies as much as democracy and what it means (Coleman and Shane 2012). Some argue that online consultations increase the level of participatory democracy by lowering the cost of participation and opening up the administrative process to individual citizens (Angeles et al. 2004). For example, at the most basic level, integrating the Internet into rulemaking makes it easier for citizens to comment on government proposals ( ̊ström and Grönlund 2012) or to participate in a shared project and collaboratively draft a comment (Noveck 2010). We should also consider that online consultations have the potential to legitimise the rulemaking process, making it easier to form and maintain virtual deliberative communities (Coleman and Gøtze 2001). Online consultations also push government agencies to open up. At the most basic level, each agency has to redesign its website and alter its existing rulemaking procedures to some degree (Jaeger and Bertot 2010); however, in the broad level, citizens' electronic participation can require agencies to reconsider their entire rulemaking process:

E-rulemaking does not fundamentally change the need for rules. What makes e-rulemaking
potentially revolutionary is that it necessitates mapping the processes of rulemaking onto
interactive software, embedding the desired practice into the design of the virtual spaces
for rulemaking. By virtue of having to 'translate' rulemaking into a set of software
specification, agency officials have to focus on the practice and precise how-to's of
rulemaking. Technology design opens the political imagination to better way of organizing,
not simply documents, but the interpersonal relationship of the rulemaking processes.
(Noveck 2010: p. 435)

Nowadays, every democratic system has some mechanisms for obtaining public inputs in policymaking processes. Examples of such tools include letters to elected politicians, public hearings, notice requirements, focus groups, surveys, citizen juries, community advisory boards and consensus conferences, among others (Dryzek 1993; Goodin 2006; Innes and Booher 2005; Parkinson 2004). Such tools invite, or at least welcome, comments by the public on important policy initiatives. However, seriously taking public feedback is another step. For example, it is out of question that governments are well positioned to control the shape of whatever discursive spaces are being opened; and we should also wonder if when public speaks, is anybody listening to it (Coleman et al. 2008).

A challenge to study online public consultations is to identify serious and systematic democratic deficits and then to devise appropriate institutional remedies. Some have argued in favour of using online public consultations as a mechanism to address such deficits while contributing to provide such remedies. Four arguments follow. 
First, online deliberative interactions offer excellent opportunities for knowledge sharing and long-term community building (Cindio and Schuler 2007; Plant 2004). Second, public consultations often devise innovative policy designs that experts alone would not have developed (Innes and Booher 2003). Third, we can argue that open discussion of matters affecting the public exposes people to other views, what enables them to evaluate the best arguments (Sunstein 2007). Fourth, they go beyond affecting outcomes of individual policymaking episodes and provide large flow of political communication within a society (Shane 2012: p. 14).

Looking from a different perspective, we may argue that online public consultation tools, instead of reducing democratic gaps, are reinforcing them. Some have argued that unequal access to the Internet skew online consultations towards more favoured groups in terms of race, geography, gender and class (Norris 2001). Others have argued that online political debate reinforces extremist beliefs and shrinks the interested public (Sunstein 2007), while others have witnessed little impact of online consultations in policymakers' decisions (Blumler and Coleman 2001). However, the most challenging argument is certainly one of scale: the basic factual point that "most exercises in online deliberation attract relatively small numbers of participants" (Shane 2012: p. 3), referring to the limited number of contributors who participate.

\subsection{Policy Design and the Policy Cycle}

For some time, policy sciences are trying to design methods to help groups articulate and structure their preferences in ways that will enable them to reach decisions that are consistent with their values and intentions. The argument supporting such quests is that to understand and explain why a policy has a particular design, we need to examine the process and the discursive practices leading to the policy's processes of design and implementation (Fischer and Hajer 1999; Schneider and Ingram 1997). Institutional arenas have rules, norms and procedures that affect choices, strategies, decisions, perceptions and preferences (Wright and Street 2007). Thus, the design of particular tools for institutional arenas has political consequences and may lead to different policy decisions (Coleman and Shane 2012).

The policymaking process can be modelled in terms of a cycle of sequential and discrete stages. Although the policy cycle perspective allows us to systematise and compare the diverse approaches in the field of policy sciences, it has been criticised in terms of its theoretical construction as well as in terms of its empirical validity (Jann and Wegrich 2007). The two main criticisms against the model refer to (1) descriptive inaccuracy, "because empirical reality does not fit with the classification of the policy process into the sequential and discrete stages", and (2) its conceptual value, because "stages model does not offer causal explanations for the transition between different stages" (p. 56). At the same time, if we read the stages model not as a perfect model to describe policymaking, rather using it to group research questions (more or less explicitly) derived from the policy cycle framework, we 
can evaluate actual impacts of particular interventions or in terms of democratic governance understand which actors are dominant and which are not:

Therefore, the policy cycle framework ... offers a perspective against which the democratic quality of these processes could be assessed (without following the assumption of a simple, discrete sequence and clear separation of stages). Additionally, the cycle framework allows the use of different analytical perspectives and corresponding research questions that will stay among the most important ones in policy research, although the stages heuristic of the policy cycle does not offer a comprehensive causal explanation for the whole policy process and even if the fundamental theoretical assumptions, on which initial versions of the framework were based, have long been left behind. (p. 58)

In general terms, the policy cycle perspective considers "the policy process as evolving through a sequence of discrete stages or phases" (Jann and Wegrich 2007: p. 44). Although a number of different variations of the stage typology have been put forward, it is largely accepted that the differentiation between agenda setting, policy formulation, decision-making, implementation and evaluation is the conventional way to describe the chronology of a policy process. Therefore, in this work, we adopt the 5-stage policy cycle model, as depicted in Fig. 1.

Among the five policy cycle stages, it has been argued that the most successful cases of citizens' participation in policymaking refer to cases where the consultation took place particularly during the agenda-setting and policy formulation stages (what we refer to as the early stages of policymaking) (Albrecht 2006; Jensen 2003; Macintosh 2003). Based on such argument and since our research focuses on these two stages, below we present more insight about agenda setting and policy formulation.

As the first policy cycle stage, agenda setting is a process of structuring the policy issue regarding potential strategies and instruments that shape the development of a policy in the subsequent stages of a policy cycle (Jann and Wegrich 2007). The agenda-setting stage focuses on problem recognition and issue selection:

An agenda is a collection of problems, understandings of causes, symbols, solutions, and other elements of public problems that come to the attention of members of the public and their governmental officials. An agenda may be as concrete as a list of bills that are before a legislature, but also includes a series of beliefs about the existence and magnitude of problems and how they should be addressed... (Birkland 2007: p. 63)

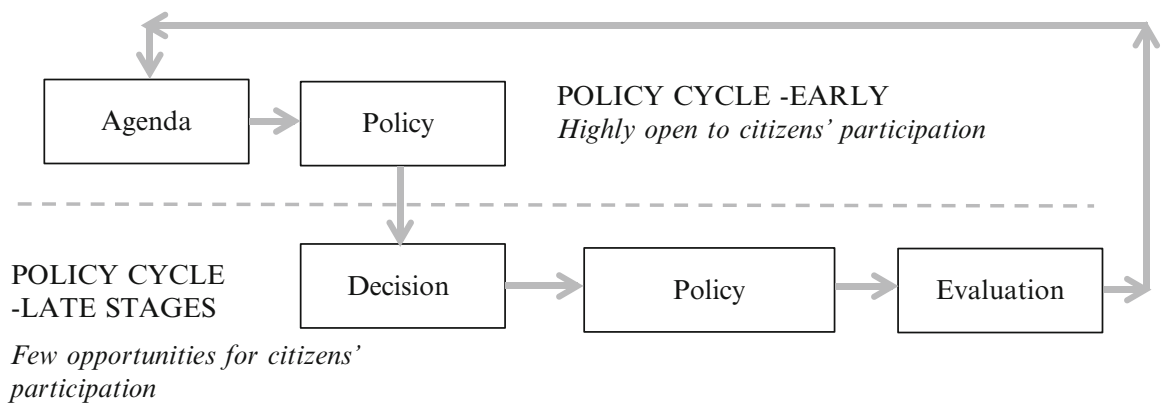

Fig. 1 Policy cycle stages 
Applying online consultations at the stage of agenda setting presupposes that government has recognised by itself a social problem and defined the necessity of state intervention. Citizen's contributions refer to suggesting a list of subjects or problems, articulating preferences, reframing problems and connecting them to relevant aspects of policymaking that should be addressed by the government, the private sector and non-profit organisations or through joint action by some or all of these institutions (Fischer 2000; Goodin 2006; Kingdon 2002).

The policy formulation stage refers to the process where expressed problems, proposals and demands are transformed into government programmes. It includes definition of objectives and the consideration of different action alternatives, drawing goals, priorities, cost-benefit trade-offs and expected externalities of available alternatives:

Formulating the set of alternatives... involves identifying a range of broad approaches to a problem, and then identifying and designing the specific sets of policy tools that constitute each approach. It involves drafting the legislative or regulatory language for each alternative ... and articulating to whom or to what they will apply, and when they will take effect. Selecting from among these a smaller set of possible solutions from which decisionmakers actually will choose involves applying some set of criteria to the alternatives, for example judging their feasibility, political acceptability, costs, benefits, and such. (Sidney 2007: p. 79)

The policy formulation stage expects fewer participants to be involved when compared to the stage of agenda setting and expects more of the work to take place out of the public eye. Most of policy formulation requires expert knowledge, which includes government bureaucrats, legislative committee rooms and think tanks (Fischer 2000; Kingdon 2002). Nonetheless, consultations related to formulating policy take up a variety of issues and can redefine the interests of those involved and the balance of power held by participants. It is expected for citizens to participate in policy formulation as well. However, because few voices are able to engage simultaneously in policy formulation, any large-scale argumentation forum is a challenging set-up at this state of policymaking.

\subsection{Web 2.0 Tools and Models of Democratic Communication}

Web 2.0 tools refer to the new generation of ICT tools and functionality enabling the design of websites beyond the static pages used in the web. The concept refers to various changes applied to the design and usage of web pages. Examples of Web 2.0 tools, as referred in this work, include social media-like Facebook, Twitter, blogs, online forums as well as functionality enabling the use of avatars (nicknames), the inclusion of tags to content of web pages and later the retrieval of content based on such tags, among others.

The basic observation that technological design of ICT tools can produce political consequences is well documented (Street 1992; Winner 1980), and a number of scholars have applied this perspective to the study of online spaces (Beierle 2004; Coleman and Gøtze 2001; Fishkin 2009; Freelon 2010; Sack 2005; Taylor 
and Preece 2010; van der Heijden 2003; Wright and Street 2007; Wright 2006). Related to this area of study, another number of scholars have proposed several policy designs intended to increase the capacity of ordinary citizens to participate in policy development and implementation (Fischer 2003; Hajer and Wagenaar 2003; Macintosh 2003), and the same can be said about governmental programmes oriented to foster citizen's participation online (Noveck 2010; Tambouris and Tarabanis 2007).

If we consider that online discussion forums can influence politics, we can argue that online space design choices can powerfully influence the nature of citizens' engagement and have a real effect on political participation and deliberation (Wright and Street 2007). To evaluate the role of Web 2.0 tools in online policy consultation, we concentrate on indicative attributes of democratic forums. The framework adopted in this work comes from Freelon (2010), who based on the work of Jürgen Habermas (1996) and Lincoln Dahlberg (2001) identifies three distinct, overlapping models of democracy that online political forums may manifest: (1) the liberal individualist, (2) the communitarian and (3) the deliberative democracy. The three models may overlap, and this is likely to happen. For each model, the framework also defines a set of indicative attributes. As Freelon explains, "what the framework contributes is a suite of normative standards for conversation quality that advances the literatures to which it is applied by introducing new conceptual distinctions between divergent notions of democracy" (p. 12). The framework is presented in Table 1.

In search of a model to understand how different kinds of public spheres exist and to measure conversation in itself, Freelon's three-model typology describes communication characteristics of online political communities, specified in terms of coherent clusters of indicative attributes. The liberal individualist model encompasses characteristics of online conversation involving personal expression and the pursuit of self-interest. The communitarian model upholds the cultivation of social cohesion and group identity; and the deliberative democracy model is marked by rational-critical arguments, by focusing on public issues and putative equality. The full list of indicative attributes for each model is shown in Table 1 and discussed in detail via our research question that states that Web 2.0 tools, when combined, generate different models of democratic environments which in turn addresses different indicative attributes of political communication.

\section{Methodology}

We address in this paper two research questions: (1) what aspects of Web 2.0 tools are used by online consultations and (2) what democratic environments are generated by combining different Web 2.0 tools. These questions are addressed based on a combination of models of democratic communication and their attributes (see Table 1), and as we have argued, we do not intend to understand what models provide higher impact on democracy or if they can exist alone or only in combined 
Table 1 Three models of online democratic communication and their indicative attributes

\begin{tabular}{|c|c|c|}
\hline Model of democratic communication & $\begin{array}{l}\text { Indicative } \\
\text { attribute }\end{array}$ & What the attribute stands for \\
\hline \multirow{4}{*}{$\begin{array}{l}\text { Liberal individualist } \\
\text { Encompasses characteristics of online } \\
\text { conversation involving personal } \\
\text { expression and the pursuit of self-interest. } \\
\text { It refers to the "democratic traditions, } \\
\text { which posit the individual as a rational, } \\
\text { autonomous subject who knows and can } \\
\text { express their own best interests. This } \\
\text { knowing subject is assumed by a diversity } \\
\text { of liberal democratic theories, from } \\
\text { classic liberalism to libertarianism" } \\
\text { (Dahlberg 2001: p. 160) }\end{array}$} & Monologue & $\begin{array}{l}\text { The individual pursuit of his } \\
\text { or her own interest (in opinion } \\
\text { expression) at the expense of } \\
\text { dialogue }\end{array}$ \\
\hline & $\begin{array}{l}\text { Personal } \\
\text { revelation }\end{array}$ & $\begin{array}{l}\text { The disclosure of information } \\
\text { about oneself in a public } \\
\text { forum }\end{array}$ \\
\hline & $\begin{array}{l}\text { Personal } \\
\text { showcase }\end{array}$ & $\begin{array}{l}\text { Advertising platforms for } \\
\text { content that individuals have } \\
\text { created apart from the forum } \\
\text { itself (i.e. other than standard } \\
\text { text posts), be it visual, aural } \\
\text { or textual }\end{array}$ \\
\hline & Flaming & $\begin{array}{l}\text { Engaging in flaming to derive } \\
\text { personal satisfaction by } \\
\text { harassing political opponents, } \\
\text { releasing tension associated } \\
\text { with suppressing their } \\
\text { unpopular opinions in offline } \\
\text { life or simply antagonising } \\
\text { others for its own sake }\end{array}$ \\
\hline \multirow{5}{*}{$\begin{array}{l}\text { Communitarian } \\
\text { Upholds the cultivation of social cohesion } \\
\text { and group identity. It "argues that } \\
\text { sustainable democracy must be based } \\
\text { upon the shared values and conceptions } \\
\text { of 'the good' that bind people into } \\
\text { community ... the communitarian self is } \\
\text { understood to be constituted within } \\
\text { relationships structured by social roles } \\
\text { and shared subjectivity. Democratic } \\
\text { dialogue serves the common life of the } \\
\text { group... it enables members of a } \\
\text { community to discover their shared } \\
\text { identity and purpose" (Dahlberg } 2001 \text { : } \\
\text { p. 163) }\end{array}$} & $\begin{array}{l}\text { Ideological } \\
\text { homophyly }\end{array}$ & $\begin{array}{l}\text { The proposition that citizens } \\
\text { tend to assemble themselves } \\
\text { into politically homogeneous } \\
\text { collectives that rarely engage } \\
\text { with outsiders }\end{array}$ \\
\hline & Mobilisation & $\begin{array}{l}\text { The promotion of conducive } \\
\text { atmosphere for the } \\
\text { furtherance of collective } \\
\text { political objectives }\end{array}$ \\
\hline & $\begin{array}{l}\text { Community } \\
\text { identification }\end{array}$ & $\begin{array}{l}\text { The extent to which } \\
\text { participants view themselves } \\
\text { as members of a community, } \\
\text { such as the use of community } \\
\text { language and collective } \\
\text { pronouns }\end{array}$ \\
\hline & $\begin{array}{l}\text { Intra-ideological } \\
\text { response }\end{array}$ & $\begin{array}{l}\text { Conversational } \\
\text { communication primarily } \\
\text { established with ideological } \\
\text { similar persons (i.e. in-group } \\
\text { members) }\end{array}$ \\
\hline & $\begin{array}{l}\text { Intra-ideological } \\
\text { questioning }\end{array}$ & $\begin{array}{l}\text { Questioning, as users must } \\
\text { respond to each other in order } \\
\text { to ask direct questions, } \\
\text { addressed to ideological } \\
\text { in-group members }\end{array}$ \\
\hline
\end{tabular}


Table 1 (continued)

\begin{tabular}{|c|c|c|}
\hline Model of democratic communication & $\begin{array}{l}\text { Indicative } \\
\text { attribute }\end{array}$ & What the attribute stands for \\
\hline \multirow{6}{*}{$\begin{array}{l}\text { Deliberative democracy } \\
\text { Pursues rational-critical arguments, by } \\
\text { focusing on public issues and putative } \\
\text { equality. "For both liberal individualism } \\
\text { and communitarianism, the source of } \\
\text { democratic legitimacy (and rationality), is } \\
\text { based upon the will of all, which is } \\
\text { derived from the expression of already } \\
\text { formed wills ... In contrast, deliberative } \\
\text { democracy relies upon inter-subjectivity. } \\
\text { All pre-discursive interests and values are } \\
\text { up for grabs. A legitimate (and rational) } \\
\text { decision rests not upon the expression of } \\
\text { pre-given wills but upon the deliberative } \\
\text { process by which everyone's will is } \\
\text { formed" (Dahlberg 2001: p. 168) }\end{array}$} & $\begin{array}{l}\text { Rational-critical } \\
\text { argument }\end{array}$ & $\begin{array}{l}\text { The willingness (to say } \\
\text { nothing of the ability) to use } \\
\text { logical, methodical appeals to } \\
\text { the common good in arguing } \\
\text { for one's position }\end{array}$ \\
\hline & $\begin{array}{l}\text { Public issue } \\
\text { focus }\end{array}$ & $\begin{array}{l}\text { Discussions focusing } \\
\text { primarily on issues } \\
\text { traditionally considered } \\
\text { political }\end{array}$ \\
\hline & Equality & $\begin{array}{l}\text { Equality is operationalised as } \\
\text { the extent to which forum } \\
\text { contributions are spread } \\
\text { evenly among participants } \\
\text { (the opposite case of a small } \\
\text { number of users contributing } \\
\text { the vast majority of posts) }\end{array}$ \\
\hline & $\begin{array}{l}\text { Discussion topic } \\
\text { focus }\end{array}$ & $\begin{array}{l}\text { As distinct from public issue } \\
\text { focus, discussion topic focus } \\
\text { assesses the extent to which } \\
\text { posts within discussion } \\
\text { threads address the initial } \\
\text { thread topic }\end{array}$ \\
\hline & $\begin{array}{l}\text { Inter-ideological } \\
\text { response }\end{array}$ & $\begin{array}{l}\text { Participants actually } \\
\text { communicate across lines of } \\
\text { difference to fully realise the } \\
\text { ideal of debate }\end{array}$ \\
\hline & $\begin{array}{l}\text { Inter-ideological } \\
\text { questioning }\end{array}$ & $\begin{array}{l}\text { The asking of questions } \\
\text { between members of mutual } \\
\text { out-groups }\end{array}$ \\
\hline
\end{tabular}

Based on Freelon (2010)

forms. Nonetheless, our aim is to evaluate how these models can aid us to understand the quality of democratic communication in online forums based on the types of Web 2.0 used.

The two case studies analysed in this chapter refer to online policy consultations that took place in Brazil, and they refer each to a different policy stage. The "Marco Civil Regulatório da Internet" (MC, Civil rights regulatory framework for Internet) ran a public portal to consult citizens on a drafted bill of Internet rights, hosting therefore a "policy formulation" online consultation (Segurado 2011; Steibel and Beltramelli 2012). Running as an "agenda-setting policy consultation", the case of "Gabinete Digital" (GD, Digital Cabinet) invited citizens to present issues, suggestions and challenges on the theme of urban traffic in the southern city of Porto Alegre (Brisola and Leal 2012; Resende and Mata 2012). The portals were analysed based on print screens and downloaded versions of their content, collected during their own consultation periods. 
The reasons for selecting the two case studies are because of their pioneering nature and political relevance. The MC was the first major online policy consultation held in Brazil. The initiative was led by the Ministry of Justice, working with the Ministry of Culture and the civil society think tank Centre for Technology and Society (FGV-RJ, Centro de Tecnologia e Sociedade). The general objective of the MC project was to draft a bill of law for the Internet in Brazil, and it was based on collaborative practices. The project ran from October 2009 to May 2010 (in two phases of 45-day each, with a break period in between) and resulted in an online forum where stakeholders interested in the topic could post, debate and comment on the possible design of future Internet legislation, attracting as a whole over 2,000 contributions and considerable amount of media coverage (Steibel and Beltramelli 2012).

The MC consultation made use of several Web 2.0 tools (mainly a WordPress platform, Twitter, RSS feeds and blogs). Divided into two rounds of discussion, people were first invited to comment on a white paper with a set of general ideas to broadly orient the draft legislation, and later citizens were invited to comment on the draft legislation as formatted to be sent to Congress. As the policymakers involved in the process describe the initiative, the first round of consultation tested a set of normative standards, predefined by those sponsoring the initiative, that were considered important to include in future legislation, while the second round focused on receiving feedback on the draft itself (Steibel and Beltramelli 2012: p. 96).

The second case study analysed, the GD, is the first online consultation portal run by a state-level government to achieve significant number of participants (Brisola and Leal 2012). Released in May 2011, the portal had previously made use of a wide range of public consultations (some of them include answering questions posted by citizens through YouTube and others like the one under analysis designed as proper agenda-setting consultations). In this chapter, we analyse the last agenda-setting consultation run in the GD portal on road traffic. The consultation ran in two phases: in the first phase, citizens could submit policy propositions related to five themes of policy agendas, where 2,100 policy suggestions where made; in the second phase, policymakers grouped the previous submissions in 600 policy propositions that were voted by citizens online (more than 240,000 votes, given by 100,000 registered citizens, were received during this phase). As a result of the consultation, the top 10 policies voted by citizens were prioritised by government and selected for policy formulation and implementation.

The GD consultation also made use of several Web 2.0 tools (mainly HTML5, YouTube, Twitter, Facebook, RSS feeds and blog). Divided into two rounds of consultation, the portal was inspired by the "All our ideas" project, the wiki survey tool which is an academic initiative from the Department of Sociology at Princeton University, and sponsored by Google (Salganik and Levy 2012). Using such a platform, the portal allowed citizens and users to write and publish online short policy programmes that were at the end of the phase analysed and merged by policymakers and grouped in five thematic groups of policy propositions. During the second phase, users were presented with a pair of random ideas selected out of the existing proposal and belonging to the same theme and asked to choose between 
them. After making this vote, participants were immediately presented with another randomly selected pair of ideas. All phases were supported by strong use of other network sites sponsored by the project leaders.

In the next section, we first analyse the Web 2.0 tools used in each portal, grouping them according to their features. We then match the possible uses of Web 2.0 tools selected with the models of communication and attributes suggested by Freelon (2010).

\section{Case Study Analyses}

This section compares the Web 2.0 tools used in each case study, aligning them with the three democratic models presented in Sect. 2.3.

\subsection{Web 2.0 Tools Used}

The first note we should describe refers to the overall objective of each portal. The MC portal was designed as a document-centred website: a bill of law. The portal is based on a WordPress content management system ${ }^{1}$ and is hosted in a multiuser WordPress server sponsored by the Ministry of Culture, the CulturaDigital.br server (Savazoni and Cohn 2009). Due to these characteristics, the portal is actually a blogging tool, and it had to be adapted to work as a document-centred website in which users could comment in a set of policies online. The initiative made use of a blog section as well, but the consultation itself had to adapt from the original use of the portal to work. Due to similarities shared between a static page and the overall structure of a legal document (i.e. a document written in short textual parts: chapters, articles and paragraphs), the blogging interface could easily accommodate a static page where its content (i.e. the drafted bill of law) would be able to receive comments online.

In contrast with the MC portal, the GD portal was designed from the start to host online public consultations. Written in HTML5, the portal has different templates to fit different types of consultations. The portal section "Governor replies", for example, received questions from general citizens that after a period of time were analysed by a team of policymakers, shortlisted and replied by the governor itself using YouTube videos. All these tasks are designed from scratch to be performed through the website. For example, the road traffic online public consultation analysed in this chapter was tailor-made for its purpose. Inspired by the project "All our ideas", the GD portal hosted during its first phase a web page where citizens could leave their contributions, and during the second consultation

\footnotetext{
${ }^{1}$ See more at http://developer.wordpress.com/
} 
phase, citizens were displayed with two proposal, one against each other as in battle of ideas and had to vote which one of the two they liked the most.

In terms of access and openness to contributions, the two portals used a twostage approach to design the consultation. In both portals, citizen's contributions and policies under review were visible to anyone visiting the portal's URL. However, in both cases, only registered users could post contributions. In the case of MC, comments were accepted only from users with a CulturaDigital.br's login (which was free for all and required no proof of identity). In the case of the GD, comments were accepted by users with portal's login (which was free for all and could also be completed by associating a Facebook or a Twitter account). An important difference between the profiles in the case studies analysed is that in the MC, each user received, associated to its login, a public profile that listed all contributions made by the user as well as displayed blogs, posts, pages and comments related to the user; in the GD, no user had a personal page, and therefore, citizens could not see the profile of others participating in the consultation.

In relation to tools used to integrate the consultation portal with other social networks, in both cases the portals made use of Twitter, but only GD used Facebook. In the case of MC, the portal created a public profile "@marcocivil" that was regularly updated and promoted the hashtag "\#marcocivil", which was promptly adopted by other twitters. Twitter was a very important social media for the MC initiative to use due to the social movement "\#MegaNão" which was one of the key reasons why the MC consultation started (Steibel and Beltramelli 2012). In the case of GD, the initiative also set up a Twitter account profile “@gabinetedigital", regularly updated it and started a set of hashtags to promote it, e.g. "\#gabinetedigital" and "\#GovRS". They also created a Facebook profile and its page "/gabinetedigital" was also regularly updated. They also generated a Google+ profile, which was eventually updated.

Table 2 presents a detailed comparison of Web 2.0 used by each portal. The categories and tools coded in the table were defined after a case study analysis of each portal. The starting point to categorise the Internet-based tools refers to those topics referred as benefits and challenges of e-rulemaking process (see Sect. 2). Once the list of tools was completed, these broad issues were used to collate the findings and compare both initiatives side by side.

An important note to make about both projects is that while the MC was mainly promoted as a policy consultation event (although eventually referred to as an initiative sponsored by the Ministry of Justice), the GD was regularly associated (and promoted as) an activity of the incumbent government and even as an event promoted by the governor itself. It is also important to note that in relation to other Web 2.0 tools used by the portals, both made use of RSS feeds for spreading news, and while the GD created a specific email account to receive comments from the general public, the MC did not set up such tool to consider email as a "private" technology (a one-to-one flow of communication, instead of many-tomany technologies such as Twitter and WordPress architectures) (Steibel 2012). 
Table 2 Comparison of Web 2.0 tools adopted in each case study

\begin{tabular}{l|l|l}
\hline Web 2.0 tool by functionality type & GD & MC \\
\hline $\begin{array}{l}\text { Personal identification } \\
\text { Login authentication }\end{array}$ & Yes & Yes \\
\hline Personal and public profile page & No & Yes \\
\hline User avatar & No & Yes \\
\hline Publishing contributions & No & Yes \\
\hline Comment identified by tag word & No & Yes \\
\hline Possibility to leave written contribution & Yes & No \\
\hline Text-length limitation & No & No \\
\hline Possibility to leave multimedia contribution & \multicolumn{2}{l}{} \\
\hline Sharing contributions & No & No \\
\hline User's contributions could be shared by other users & Yes & Yes \\
\hline Portal's contributions could be shared by others & \multicolumn{2}{l}{} \\
\hline Interaction with social media & Yes & No \\
\hline Portal's profile on Facebook & Yes & No \\
\hline Portal's profile on YouTube & Yes & Yes \\
\hline Portal's profile on Twitter & Yes & No \\
\hline Portal's profile on Google+ & Yes & No \\
\hline Dedicated email account & Yes & Yes \\
\hline RSS feed link & \multicolumn{2}{l}{} \\
\hline Promoting an informed debate & Yes & Yes \\
\hline Hosting a blog with experts' contribution & No & Yes \\
\hline Hosting a forum/section for citizens to exchange ideas & No & Yes \\
\hline Promotion of user's in-depth contributions in the blog & \multicolumn{2}{l}{} \\
\hline
\end{tabular}

Table 2 aids us to consider some aspects of Internet-based tool on democracy. Three arguments can be made. First, both initiatives present some tools to interact with social media; however, none of the portals have tools to hosts policy debates outside of their own environment. Social media tools are present to connect people, to promote the overall initiative and to facilitate login processes. However, links and content shared in other networks are oriented to bring citizens back to participate in the main URL. Second, the MC case uses tools to promote an informed debate more heavily than the DG case does. This is likely to be related to the difference in terms of policy cycle. It is reasonable to expect text-based comments to be more important during a policy formulation stage than during an agenda-setting stage. Third, both cases present some tools to promote personal identification. Although such tools are not based on official records, they make a clear statement that anonymous contributions are not welcomed and refer to a need for online consultations to record individual, person-based, contributions by design. 


\subsection{Web 2.0 and Democratic Models}

This section applies the Web 2.0 tools presented in Table 2 with the three models of democracy and their indicative attributes presented at the literature review. The explanation follows and the summary is presented in Table 3.

The Liberal Individualist framework considers imperative to make possible for individuals to express themselves. This framework requires Web 2.0 tools to allow citizens to create personal spaces for self-expression and to advertise their own preferences to others. In the MC portal, for example, Web 2.0 tools allow users to make their own voice heard ("monologue" attribute), while in the GD approach, citizens can express their personal opinion only in a limited way (writing a short, limited size, policy proposal). The MC portal also allows citizens to present "personal revelation"- to disclose information about oneself in a public forumwhich can be done either in the comment section and in the personal profile page and can also promote "personal showcase" because contents created by users are directly linked to them as their contributions (which in both cases cannot be done in the GD portal). We should also consider that the MC is open to "flaming" while the GD (due to the limitation in terms of tools for individual expression) is closed to it. Since "flaming" can be both democracy-enhancing and democracy-detracting conversation, it was a main concern of policymakers promoting the MC portal; however, it never occurred (Steibel and Beltramelli 2012).

The communitarian framework considers as a priority strengthening ties between citizens involved in policymaking and creating user groups by similarity of ideo-

Table 3 Analysis of case studies based on the framework of online democratic communication

\begin{tabular}{|c|c|c|c|}
\hline \multirow{2}{*}{$\begin{array}{l}\text { Model of } \\
\text { democratic } \\
\text { communication }\end{array}$} & \multirow[b]{2}{*}{ Indicative attributes } & \multicolumn{2}{|l|}{ Cases } \\
\hline & & GD & $\mathrm{MC}$ \\
\hline \multirow{4}{*}{ Liberal individualist } & Monologue & No & Yes \\
\hline & Personal revelation & No & Yes \\
\hline & Personal showcase & No & Yes \\
\hline & Flaming & No & Yes \\
\hline \multirow[t]{5}{*}{ Communitarian } & Ideological homophyly & No & Yes \\
\hline & Mobilisation & No & Yes \\
\hline & Community identification & Partly & Yes \\
\hline & Intra-ideological response & No & Partly \\
\hline & Intra-ideological questioning & No & Partly \\
\hline \multirow[t]{6}{*}{ Deliberative } & Rational-critical argument & Yes & Yes \\
\hline & Public issue focus & Yes & Yes \\
\hline & Equality & Partly & Partly \\
\hline & Discussion topic focus & Partly & Yes \\
\hline & Inter-ideological response & No & Yes \\
\hline & Inter-ideological questioning & No & Yes \\
\hline
\end{tabular}


logical alignment or social ties or both. In terms of "ideological homophyly", we should consider it as a possibility in the MC portal. However, it cannot happen in the GD portal due to the absence of interaction between users. In the same direction, "mobilization" is related to the offer of a conductive atmosphere for the furtherance of collective political objectives, an important feature to other online and also offline set-up of communitarian spaces, which can happen in the MC case but not in the GD case. Regarding "community identification", although this can be partially achieved in the GD portal (because users can view contributions of others), this cannot be fully accomplished there because people cannot align themselves to others' policy proposals (except voting on them, considering however that proposals are randomly drawn), and they cannot make use of collective pronouns such as "we", "us" and "our". In terms of "intra-ideological response" and "intra-ideological questioning", these two attributes can only happen in the MC portal, and even so, partially. In the $\mathrm{MC}$ portal, there is only one communicative arena where the consultation happens, a space shared by all participants, which does not allow discussion organised by groups to take place inside the portal.

The deliberative model is marked by Habermas' conceptual trio of (1) rationalcritical argument, (2) public issue focus and (3) putative equality. In this regard, both portals are able to promote "rational-critical argument" because tools used in each case allow citizens to be willing to use logical methodical appeals to the common good. The same is true about the "public issue focus" characteristic because it is possible in the MC and the GD portal for citizens to focus on strong public issues traditionally considered political (referring here, in the case of the MC, to civil rights related to Internet use and, in the case of the GD, to road traffic-related issues). The "equality" attribute is possible to be achieved in both portals, but cannot be measured in neither of them. Although Web 2.0 tools allow users to participate in equal terms in both cases, inequalities related to access, interest or knowledge may provide inequality as a result of tools' use in the MC and the GD. Regarding the "discussion topic focus" attribute, we notice that in the case of the GD, there is no thread of discussion allowed by tools in use (unless we consider voting in a "battle layout" as a form of thread discussion). In the case of the MC, however, the topic focus can be achieved and it's actually enforced by the use of document-centred discussion. When we analyse the "inter-ideological response" and "inter-ideological questioning", it is clear that this can only be achieved in the MC case (due to tools allowing citizens to express themselves and ask questions to others).

\section{Conclusion and Future Research}

The two research questions presented in the Introduction section were addressed respectively in Sects. 4.1 and 4.2. As regards the first research question, we mapped what Web 2.0 tools and functionalities were used in the two case studies, clustering them according to what political action they enabled citizens to achieve (i.e. enacting personal identification, publishing contributions online, sharing comments with 
others, linking different social media networks and promoting an informed debate). Pertaining to the second question, we noted that Web 2.0 tools, when combined, generate different models of democratic environments which in turn addresses different indicative attributes of political communication. Read together, our two research questions validate the perspective of Wright and Street who claim that design choices of the use of ICT in online space influence the nature of citizens' engagement and have a real effect on political participation and deliberation (Wright and Street 2007). Although our current research cannot assess real impact related to design choices, we expect future research to fill this gap by analysing the comments and interactions established in the two case studies here addressed.

We do however expect to find differential impact based on what Web 2.0 tools are in use. The presence or absence of text boxes to receive comments from users considerably restrings the use of deliberative and communitarian models. Having in mind that the policy stage of policy formulation is closely linked to attributes of these models, we can predict that this Web 2.0 tool is mandatory at this stage. Another possible prediction is that the policy stage of agenda setting requires fewer number of Web 2.0 tools than the policy formulation stage does (which is true when we consider that the GB initiative employed fewer tools than the MC did).

As we evaluate the case studies, it becomes clear that when combining Web 2.0 for online public consultation, different models of democratic communication can overlap. The overlapping of different models is predicted by Freelon, who supports that a common virtual space has little chances to adhere to a singular set of standards or to encompass all possible modes of political expression. "Thus, rather than unilaterally declaring a forum more or less 'deliberative' after analysing its contents, the new framework permits more precise conclusions such as 'communitarian with some deliberative aspects' or 'solidly liberal individualist'" (Freelon 2010: p. 6). The Web 2.0 tools used in the GD portal, for example, have the potential to deliver aspects of the deliberative model of communication, but can only partly deliver attributes of the communitarian model and are unable to deliver any aspect of the libertarian model. The MC case, however, can deliver aspects of the three models, what is particularly true regarding the libertarian and the deliberative models.

We should take into consideration that there is no normative standard arguing that one model of democracy is better than the others. Answering the question of which model is preferred to others requires defining what is the purpose of the undergoing process of policymaking. Policy study is a problem-oriented field of research (Lasswell 2003), and unless we define beforehand what is the problem to address, we cannot evaluate the impact or the success of one model over the others. We also need to consider that the ability to deliver models of communications is not the same as delivering it. To do so, we still need to evaluate the content of online public consultations, particularly the posts and contributions of general users, and evaluate if the usage of Web 2.0 tools was indeed used for the purpose they were designed for.

In future research, we plan to apply our framework to other stages of policy cycle and to evaluate, for example, if online public consultation is taken into consideration by policymakers during the decision-making stage. We also plan to 
increase the sample of observed case studies, including, particularly, websites and online platforms built with technologies other than WordPress. Finally, we realise a need to evaluate the impact of experiences among users, understanding the effect of Web 2.0 tools in strengthening citizens' engagement.

Open Access This chapter is distributed under the terms of the Creative Commons Attribution Noncommercial License, which permits any noncommercial use, distribution, and reproduction in any medium, provided the original author(s) and source are credited.

\section{References}

Albrecht, S. (2006). Whose voice is heard in online deliberation?: A study of participation and representation in political debates on the internet. Information Community and Society, 9(1), $62-82$.

Angeles, L., Sevilla, G., Shulman, S., \& Tiller, E. (2004). E-rulemaking: Bringing data to theory at the federal communications commission. Duke Law Journal, http://scholarship.law.duke.edu/ $\mathrm{dlj} / \mathrm{vol} 55 / \mathrm{iss} 5 / 3 /$.

Åström, J., \& Grönlund, Å. (2012). Online consultations in local government: What works, when, and why? In S. Coleman \& P. M. Shane (Eds.), Connecting democracy: Online consultation and the flow of political communication. Cambridge, MA/London: MIT Press.

Beierle, T. C. (2004). Digital deliberation: Engaging the public through online policy dialogues. In Democracy online: The prospects for political renewal through the Internet (Vol. 155, p. 155). Publisher: Routledge; 1 edition (August 4, 2004), ISBN-10: 0415948657, http://www. amazon.com/Democracy-Online-Prospects-Political-Internet/dp/0415948657/ref=sr_1_1?ie= UTF8\&qid $=1423535343 \& s r=8-1 \&$ keywords $=$ Democracy + online $\% 3 \mathrm{~A}+$ The + prospects + for + political+renewal+through+the+Internet.

Benjamin, S. M. (2006). Evaluating E-rulemaking: Public participation and political institutions. Duke Law School Faculty Scholarship Series. Paper 73.

Bimber, B. (2003). Information and American democracy: Technology in the evolution of political power. Cambridge: Cambridge University Press.

Birkland, T. A. (2007). Agenda setting in public policy. In F. Fischer, G. J. Miller, \& M. S. Sidney (Eds.), Handbook of Public Policy Analysis: Theory, politics and methods. Boca Raton: CRC Press.

Blumler, J. G., \& Coleman, S. (2001). Realising democracy online: A civic commons in cyberspace. IPPR/Citizens Online Papers.

Brisola, A. C., \& Leal, T. (2012). Internet e Participação: uma análise do Portal Gabinete Digital. Enagramas, 6(1), 1-15.

Chadwick, A. (2006). Internet politics: States, citizens, and new communication technologies. Oxford: Oxford University Press.

Coleman, S., \& Blumler, J. G. (2009). The internet and democratic citizenship: Theory, practice and policy (p. ix, 220). Cambridge: Cambridge University Press.

Coleman, S., \& Gøtze, J. (2001). Bowling together: Online public engagement in policy deliberation. Retrieved January. Hansard Society. London, 2002, http://www.hansardsociety. org.uk/wp-content/uploads/2012/10/Bowling-Together-Online-Public-Engagement-inPolicy-Deliberation-2001.pdf.

Coleman, S., \& Price, V. (2012). Democracy, distance, and reach: The new media landscape. In S. Coleman \& P. M. Shane (Eds.), Connecting democracy: Online consultation and the flow of political communication. Cambridge, MA/London: MIT Press. 
Coleman, S., \& Shane, P. M. (2012). Connecting democracy: Online consultation and the flow of political communication. Cambridge, MA/London: MIT Press.

Coleman, S., Morrison, D. E., \& Svennevig, M. (2008). New media and political efficacy. International Journal of Communication, 2, 771-791.

da Silva Resende, C. A., \& da Mata, J. F. (2012). Gabinete digital: uma experiência de democracia na rede. Conference OIDP, Porto Alegre, Brazil.

Dahlberg, L. (2001). Democracy via cyberspace: Mapping the rhetorics and practices of three prominent camps. New Media and Society, 3(2), 157-177.

De Cindio, F. \& Schuler, D. (2007). Deliberation and community networks: A strong link waiting to be forged. Proceedings of CIRN conference: Communities and Action (pp. 1-11), Prato.

Dryzek, J. S. (1993). Policy analysis and planning: From science to argument. In F. Fischer \& J. Forester (Eds.), The argumentative turn in policy analysis and planning (p. viii, 327). Durham: Duke University Press.

Fischer, F. (2000). Citizens, experts and the environment: The politics of local knowledge. Durham: Duke University Press.

Fischer, F. (2003). Reframing public policy: Discursive politics and deliberative practices (p. xi, 266). Oxford/New York: Oxford University Press.

Fischer, F., \& Hajer, M. (1999). Living with nature: Environmental politics as cultural discourse. Oxford: Oxford University Press.

Fishkin, J. S. (2009). When the people speak: Deliberative democracy and public consultation. Oxford/New York: Oxford University Press.

Fountain, J. E. (2003). Prospects for improving the regulatory process using e-rulemaking. Communications of the ACM, 46(1), 43-44. doi:10.1145/602421.602445.

Freelon, D. G. (2010). Analyzing online political discussion using three models of democratic communication. New Media and Society, 12(7), 1172-1190. doi:10.1177/1461444809357927.

Goodin, R. E. (2006). Deliberative impacts: The macro-political uptake of mini-publics. Politics and Society, 34(2), 219-244. doi:10.1177/0032329206288152.

Habermas, J. (1996). Between facts and norms: Contributions to a discourse theory of law and democracy. Cambridge, MA: MIT Press.

Hajer, M., \& Wagenaar, H. (2003). Deliberative policy analysis: Understanding governance in the network society. Cambridge: Cambridge University Press.

Innes, J. E., \& Booher, D. E. (2003). Collaborative policymaking: Governance through dialogue. In M. A. Hajer \& H. Wagenaar (Eds.), Deliberative policy analysis: Understanding governance in the network society (pp. 33-60). Cambridge: Cambridge University Press Cambridge.

Innes, J. E., \& Booher, D. E. (2005). Reframing public participation: Strategies for the 21 st century. Planning Theory and Practice, 5(4), 33-60.

Jaeger, P. T., \& Bertot, J. C. (2010). Transparency and technological change: Ensuring equal and sustained public access to government information. Government Information Quarterly, 27(4), 371-376. doi:10.1016/j.giq.2010.05.003.

Jann, W., \& Wegrich, K. (2007). Theories of the policy cycle. In F. Fischer, G. J. Miller, \& M. S. Sidney (Eds.), Handbook of public policy analysis: Theory, politics and methods. Boca Raton: CRC Press.

Jensen, J. L. (2003). Virtual democratic dialogue ? Bringing together citizens and politicians. Information Polity, 8, 29-47.

Kingdon, J. W. (2002). Agendas, alternatives, and public policies (Longman classics edition). New York: Longman.

Lasswell, H. D. (2003). The policy orientation. In H. D. Lasswell, D. Lerner, \& S. Braman (Eds.), Communication researchers and policy-making. Cambridge, MA/London: MIT Press/Stanford University Press.

Macintosh, A. (2003). Promise and problems of E-democracy: Challenges of online citizen engagement. OECD Publishing. doi:10.1787/9789264019492-en. Leeds, UK.

Norris, P. (2000). A virtuous circle: Political communications in postindustrial societies (p. xvii, 398). Cambridge: Cambridge University Press. 
Norris, P. (2001). Digital divide: Civic engagement, information poverty, and the Internet worldwide (Vol. 40). Cambridge: Cambridge University Press. http://www.cambridge.org/ar/ academic/subjects/politics-international-relations/comparative-politics/digital-divide-civicengagement-information-poverty-and-internet-worldwide.

Noveck, B. S. (2010, November 2). Wiki government: How technology can make government better, democracy stronger, and citizens more powerful (p. xxii, 224). Brookings Institution Press; Reprint edition (November 2, 2010), ISBN-10: 0815705107. Washington, DC: Brookings Institution Press. http://www.amazon.com/Wiki-Government-TechnologyDemocracy-Stronger/dp/0815705107/ref=sr_1_1?ie=UTF8\&qid=1423535280\&sr=8-1\& keywords=wiki+government

O'Reilly, T. (2005). What is Web 2.0? Design patterns and business models for the next generation of software. Author's webpage.

Parkinson, J. (2004). Hearing voices: Negotiating representation claims in public deliberation. The British Journal of Politics and International Relations, 6(3), 370-388. http://onlinelibrary. wiley.com/doi/10.1111/j.1467-856X.2004.00145.x/abstract.

Plant, R. (2004). Online communities. Technology in Society, 26(1), 51-65. doi:10.1016/j.techsoc. 2003.10.005.

Postigo, H. (2011). Questioning the web 2.0 discourse: Social roles, production, values, and the case of the human rights portal. The Information Society, 27(3), 181-193.

Sack, W. (2005). Discourse architecture and very large-scale conversation. In R. Latham \& S. Sassen (Eds.),Digital formations: IT and new architectures in the global realm. Princeton: Princeton University Press.

Salganik, M. J., \& Levy, K. E. C. (2012). Wiki surveys: Open and quantifiable social data collection*. http://arxiv.org/abs/1202.0500, pp. 1-29.

Savazoni, R., \& Cohn, S. (2009). Cultura digital.br (R. Savazoni \& S. Cohn, Eds.) (p. 312). Rio de Janeiro: Beco do Azougue.

Schneider, A. L., \& Ingram, H. M. (1997). Policy design for democracy. Lawrence: University Press of Kansas.

Segurado, R. (2011). Política da Internet: a regulamentação do ciberespaço. Confibercom. Revistausp, 90, doi:http://dx.doi.org/10.11606/issn.2316-9036.v0i90p43-57.

Shane, P. M. (2004). Democracy online: The prospects for political renewal through the internet. New York: Routledge.

Shane, P. M. (2012). Online consultation and political communication in the era of obama: An introduction. In S. Coleman \& P. M. Shane (Eds.), Connecting democracy: Online consultation and the flow of political communication. Cambridge, MA/London: MIT Press. (Kindle.). Kindle edition.

Sidney, M. S. (2007). Policy formulation: Design and tools. In F. Fischer, G. J. Miller, \& M. S. Sidney (Eds.),Handbook of public policy analysis: Theory, politics and methods. Boca Raton: CRC Press.

Steibel, F. (2012). Ferramentas Web 2.0 e o design de consultas públicas online: o caso do Marco Civil Regulatório. Compos, GT Comunicação e Democracia, Juiz de Fora, Brazil.

Steibel, F., \& Beltramelli, F. (2012). Policy, research and online public consultations in Brazil and Uruguay. In B. Girard \& E. A. y Lara (Eds.), Impact 2.0: New mechanism for linking research and policy. Montevideo: Fundación Comuca.

Street, J. (1992). Politics \& technology. London: MacMillan.

Sunstein, C. R. (2007). Republic.com 2.0. Princeton: Princeton University Press.

Tambouris, E., \& Tarabanis, K. (2007). DEMO-net: D14.3 The role of Web 2.0 technologies in eParticipation. DEMO-net consortium, Leeds, UK.

Taylor, P., \& Preece, J. (2010). Determining and measuring success Sociability and usability in online communities: Determining and measuring success. Behaviour and Information Technology, 20(5), 37-41. doi:10.1080/0144929011008468.

Van der Heijden, H. (2003). Factors influencing the usage of websites: The case of a generic portal in The Netherlands. Information and Management, 40(6), 541-549. doi:10.1016/S03787206(02)00079-4. 
Winner, L. (1980, Winter). Do artifacts have politics? (In D. MacKenzie \& J. Wajcman, Eds. Modern technology: Problem or opportunity?). Daedalus, 109(1), 121-136. http://innovate. ucsb.edu/wp-content/uploads/2010/02/Winner-Do-Artifacts-Have-Politics-1980.pdf

Wright, S. (2006). Government-run online discussion fora: Moderation, censorship and the shadow of control. The British Journal of Politics and International Relations, 8(4), 550-568.

Wright, S., \& Street, J. (2007). Democracy, deliberation and design: The case of online discussion forums. New Media and Society, 9(5), 849-869. doi:10.1177/1461444807081230. 